\title{
Numerical calculations of conditions for the separation of black oil from Lower Paleozoic shale formations
}

\begin{abstract}
Numerical simulations were carried out for the process of the one-stage separation of reservoir fluid using the example of black oil from Polish Lower Paleozoic shale formations. As a result of tests conducted on reservoir fluid samples obtained from wells drilled in the Lower Paleozoic formations of the Baltic-Podlasie-Lublin Basin (on PGNiG and Orlen Upstream concessions), compositions of reservoir fluid were determined.
\end{abstract}

Key words: reservoir fluid separation, shale formations.

\section{Obliczenia numeryczne warunków separacji ropy black oil z dolno paleozoicznych formacji łupkowych}

Przeprowadzono symulacje numeryczne procesu I stopniowej separacji płynu złożowego na przykładzie ropy black oil z polskich dolno paleozoicznych formacji łupkowych. Składy płynu złożowego uzyskano na podstawie przeprowadzonych badań próbek pozyskanych z pozytywnie wykonanego jednego z odwiertów w dolno paleozoicznych formacjach basenu bałtycko-podlasko-lubelskiego na koncesjach PGNiG oraz Orlen Upstream.

Słowa kluczowe: separacja płynu złożowego, formacje łupkowe.

\section{Introduction}

A reservoir fluid, specified as black oil, was found in positively drilled wells in the Lower Paleozoic formations of the Baltic-Podlasie-Lublin Basin on PGNiG and Orlen Upstream concessions $[3,6]$. The method of such oil management requires analyses and controls both of transport phenomena occurring in the deposit, as well as developing the most effective conditions and methods for its separation on the surface. This paper focuses on the latter aspect.

The information about oil extraction from shale formation deposits worldwide is incomplete. Studies on unconventional gas deposits have been going on for many years, but the data related to the technical aspects of oil extraction from shale is more scarce. Only the report published in the USA by the EIA (Energy Information Administration) in 2013 [2] partly provides this information. On the continent of North America the largest deposit of oil from shale is the Bakken formation, situated in the area of the states of North Dakota and Montana, and in Canada (in the western bay of the Eagle Ford basin, and in the Williston basin), where oil extraction of more than 1 million barrels daily was recorded in April 2014 , while a certain part of this production is not related to oil from shale formations (confirmed by the Canadian National Energy Board). Companies carrying out extraction have also expanded the knowledge of geological structure formations and rules for their mining [5]. One of the most important rules (objectives) of extraction is the active control of GOR (gas oil ratio), through such maintenance and management of the formation pressure as to prevent its substantial drop below the saturation pressure, causing a threat of generating unwanted amounts of free gas, which affects the fluid (oil and water) flows. As in conventional formations, a lower saturation pressure usually reduces the GOR value, and the oil loses the 
capacity to store dissolved gas. Sometimes such situations are difficult to avoid, and it is necessary to expect variable compositions of reservoir fluid appearing at the head $[1,7]$.
This paper is aimed at the analysis of separation conditions for a selected black oil type reservoir fluid obtained from a shale formation in the area of Poland.

\section{Examined material}

During the research work performed so far under the task named Determination of the composition, phase properties and PVT parameters of the reservoir fluid in individual extraction fields (the Blue Gas ResDew Programme), samples were taken from wells made available in Lower Paleozoic formations (Ordovician, Sylurian).

The fluid of composition provided in Table 1 was chosen as the examined material.

Table 1. Chemical composition of black oil, saturated, from shale formations

\begin{tabular}{|c|c|c|c|}
\hline Component & {$[$ mole $\%]$} & Component & [mole \%] \\
\hline $\mathrm{He}$ & 0.239 & $\mathrm{C}_{10}$ & 2.301 \\
\hline $\mathrm{N}_{2}$ & 2.458 & $\mathrm{C}_{11}$ & 1.538 \\
\hline $\mathrm{CO}_{2}$ & 0.563 & $\mathrm{C}_{12}$ & 1.397 \\
\hline $\mathrm{C}_{1}$ & 41.112 & $\mathrm{C}_{13}$ & 1.268 \\
\hline $\mathrm{C}_{2}$ & 7.982 & $\mathrm{C}_{14}$ & 1.151 \\
\hline $\mathrm{C}_{3}$ & 5.572 & $\mathrm{C}_{15}$ & 1.045 \\
\hline $\mathrm{iC}_{4}$ & 0.642 & $\mathrm{C}_{16}$ & 0.948 \\
\hline $\mathrm{nC}_{4}$ & 3.668 & $\mathrm{C}_{17}$ & 0.861 \\
\hline $\mathrm{iC}_{5}$ & 0.662 & $\mathrm{C}_{18}$ & 0.781 \\
\hline $\mathrm{nC}_{5}$ & 3.973 & $\mathrm{C}_{19}$ & 0.709 \\
\hline $\mathrm{C}_{6}$ & 3.861 & $\mathrm{C}_{20}$ & 0.644 \\
\hline $\mathrm{C}_{7}$ & 4.039 & $\mathrm{C}_{21+}$ & 6.320 \\
\hline $\mathrm{C}_{8}$ & 3.711 & $\mathrm{GOR}_{2}$ & $189 \mathrm{Nm} / \mathrm{m}^{3}$ \\
\hline $\mathrm{C}_{9}$ & 2.556 & $\rho_{20}$ & $0.8230 \mathrm{~g} / \mathrm{cm}^{3}$ \\
\hline
\end{tabular}

\section{Oil separation tests}

At the beginning, an assumption was made that the reservoir fluid from a shale formation containing black oil would be degassed to a pressure allowing a high receipt of oil. Experimental tests were carried out in the PVT Laboratory, where such fluid (recombined) was degassed at various pressures at room temperature, which is presented in Fig. 1.

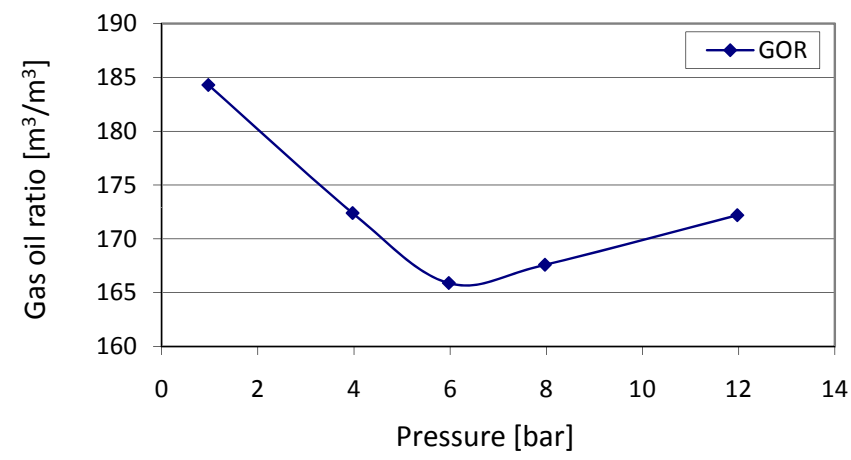

Fig. 1. Gas liquid ratios from the reservoir fluid [4]
As results from reservoir fluid degassing tests, the lowest value of the gas-oil ratio, GOR, is achieved at the separation pressure of around 6 bar. Such simulation conditions will be considered in further analyses.

Fig. 2 presents a working diagram designed using the ChemCAD software for numerical calculations of black oil type reservoir fluid separation, with a composition as in Table 1. Heater (4) and pressure-reducing valves $(5,6)$ allow the simulation of appropriate conditions of equilibrium separation (in flash 1 and 3 apparatuses).

Based on this diagram (Fig. 1), Table 2 specifies an example composition of black oil separation gas streams, at a pressure of 6 bar and at $25^{\circ} \mathrm{C}$ (separation stage I) and 0.1 bar, $11^{\circ} \mathrm{C}$ (separation stage II). A Soave-Redlich-Kwong model of phase equilibria (SRK - version SRK/PR BIPs) was used in the calculations. The pressure and temperature at the head are limitations in any development of oil degassing 


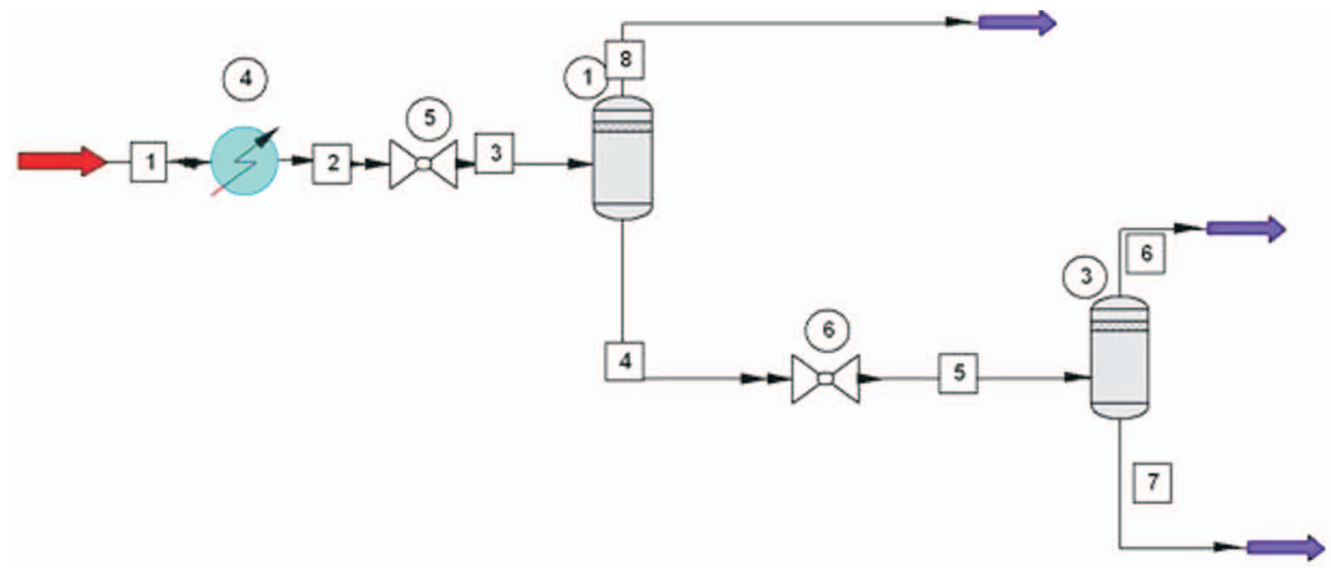

Fig. 2. Working diagram designed using the ChemCAD software for numerical calculations of black oil type reservoir fluid separation

from oil is more favourable at temperatures higher than room temperature due to the emulsions which can form.

In numerical calculations using the ChemCAD software, for separation pressures of 3, 6 and 10 bar for the stream, three actual gas oil ratios were calculated (values are given converted to standard conditions), in the temperature range from 2 to around $70^{\circ} \mathrm{C}$, which is presented in Fig. 3.

Table 2. Specification of black oil separation gas streams

\begin{tabular}{|c|c|c|}
\hline Gas & $\begin{array}{c}\text { Stream } 8 \text { composition } \\
6 \text { bars, } 25^{\circ} \mathrm{C}\end{array}$ & $\begin{array}{c}\text { Stream } 6 \text { composition } \\
0.1 \text { bar, } 11^{\circ} \mathrm{C}\end{array}$ \\
\hline $\mathrm{He}$ & 0.421 & 0.014 \\
\hline $\mathrm{N}_{2}$ & 4.314 & 0.243 \\
\hline $\mathrm{CO}_{2}$ & 0.908 & 0.531 \\
\hline $\mathrm{C}_{1}$ & 70.919 & 11.494 \\
\hline $\mathrm{C}_{2}$ & 12.326 & 10.706 \\
\hline $\mathrm{C}_{3}$ & 6.526 & 18.853 \\
\hline $\mathrm{C}_{4}$ & 2.843 & 23.292 \\
\hline $\mathrm{C}_{5}$ & 1.236 & 21.969 \\
\hline $\mathrm{C}_{6}$ & 0.345 & 8.810 \\
\hline $\mathrm{C}_{7+}$ & 0.162 & 4.088 \\
\hline
\end{tabular}

PVT conditions. Assuming that the fluid head pressure will be around $100 \mathrm{bar}$, then after a reduction to a few bar it will be cooled down by a dozen or so degree Celsius, which is related to the presence of the gas phase. Table 3 presents simulations of temperature changes for various cases, carried out for the gas composition from Table 1, using the ChemCAD software.

Table 3. Temperature drop at the reduction of reservoir fluid pressure

\begin{tabular}{|c|c|c|c|}
\hline \multirow{2}{*}{$\begin{array}{l}\text { Temperature } \\
\text { before reduction } \\
\quad\left[{ }^{\circ} \mathrm{C}\right]\end{array}$} & \multicolumn{3}{|c|}{$\begin{array}{l}\text { Temperature drop at the reduction of oil pressure } \\
\qquad\left[{ }^{\circ} \mathrm{C}\right]\end{array}$} \\
\hline & 100 bars $\rightarrow 3$ bars & 100 bars $\rightarrow 6$ bars & 100 bars $\rightarrow 10$ bars \\
\hline 55 & 18.4 & 14.5 & 11.7 \\
\hline 33 & 17.9 & 14.4 & 11.7 \\
\hline 20 & 17.9 & 14.5 & 11.9 \\
\hline
\end{tabular}

The water content in a raw reservoir fluid may be another limitation at lower temperatures. This will not be discussed in this paper, but in real conditions the water phase separation
As Fig. 3 shows, with increasing separation temperature, the total amount of gas released from oil grows. Compositions of separated gases (stream 8) change under various conditions, which is presented in the following graphs: 4 , 5, 6 using the example of methane, ethane, propane, and hexane content.

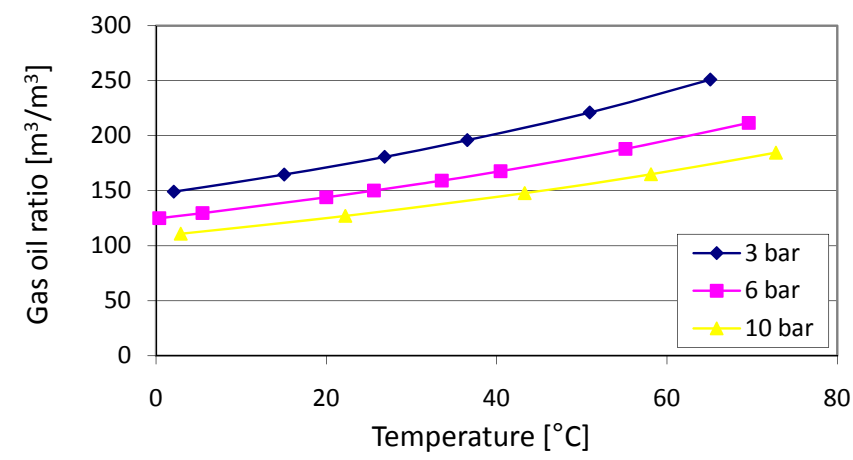

Fig. 3. Development of GORs (actual conditions) versus temperature, for various pressures

Methane content in the gas released during oil separation goes down with increasing temperature, despite its having the largest share in the gas volume. This is caused by the increasing share of higher hydrocarbons in the gas composition with rising temperature of oil degassing.

Ethane content in the gas released during oil separation has a diversified course with increasing temperature. At the separation pressure of 3 bar the highest ethane concentration is obtained at lower temperatures, and its content diminishes with heating the system. At slightly higher separation pressures (6 and 10 bar) the ethane share in the volume of released gas initially grows, reaching a maximum at approx. $30^{\circ} \mathrm{C}$ for the pressure of 6 bar and at around $50^{\circ} \mathrm{C}$ for the pressure of 10 bar. This effect is 
interesting from the point of view of the most effective use of the obtained gas as a basic source for ethane production.

Contrary to methane, the propane content in the gas released during the oil separation goes up with increasing temperature. The pace of propane concentration growth in the gas is highest in the lower range of temperatures used, while at higher temperatures it approaches a plateau or maximum, as ob-

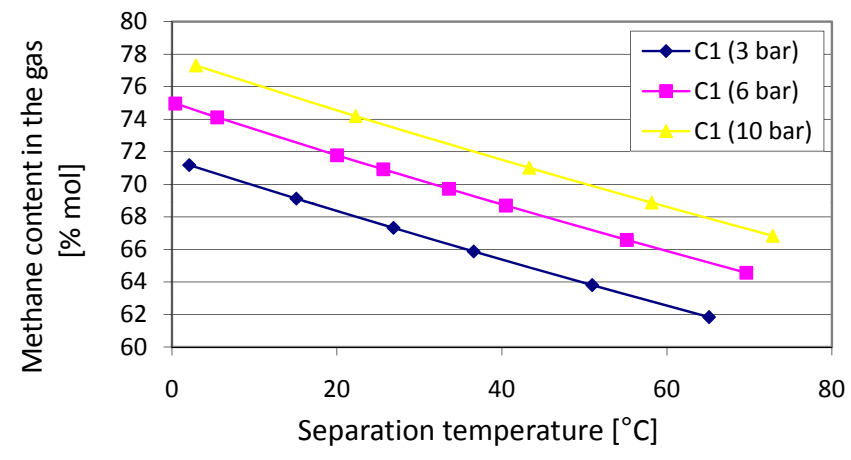

Fig. 4. Methane content in the gas released during oil separation

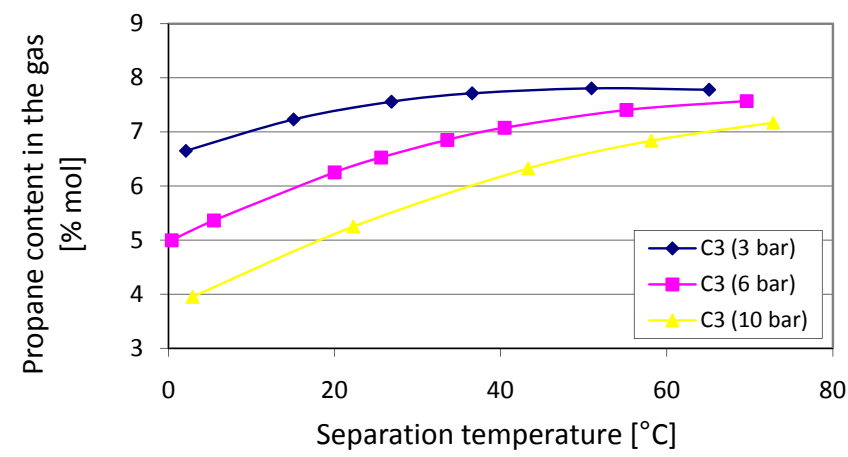

Fig. 6. Propane content in the gas released under different conditions of oil separation served in the case of ethane at slightly lower temperatures. Fig. 7 presents a comparison of higher hydrocarbons content based on a hexane example versus temperature, for various separation pressures.

As Fig. 7 shows, with increasing temperature of oil degassing the hexane content in the gas initially grows slowly, and then the increase in its amount is faster.

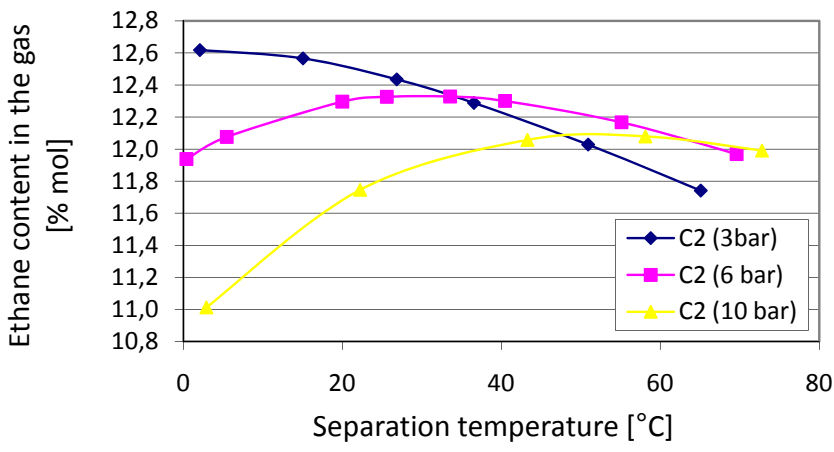

Fig. 5. Ethane content in the gas released during oil separation

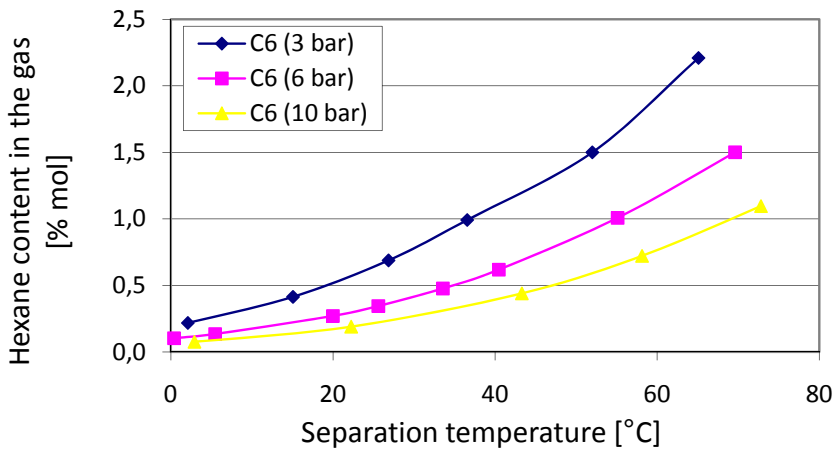

Fig. 7. Hexane content in the gas released under different conditions of oil separation

\section{Summary}

The results of oil separation to a large extent affect the level of its extraction (for reservoirs of low pressure value, e.g. at a late stage of mining) and the composition of the raw gas obtained in this process. Based on numerical calculations using the engineering software ChemCAD, an especially significant influence has been found of temperature on the development of individual hydrocarbon concentrations in the gas.

It has been found that the methane content in the gas released during oil separation goes down with increasing temperature, despite its having the largest share in the gas volume, whose amount grows with increasing temperature. This is caused by the increasing share of higher hydrocarbons in the gas composition with rising temperature of oil degassing.

In the temperature range examined in calculations, in the ethane content course, it has been observed to reach a maximum concentration, which may be used in potential technologies to produce an ethane concentrate valuable in the industry.

A thorough observation of hydrocarbon concentration development depending on stage I separation conditions also shows a possibility of a setting of separation temperature and pressure such that there may be an option in which there will be no need for stage II and oil stabilisation application. However, such an option should be analysed in more detail.

Please cite as: Nafta-Gaz 2015, no. 11, pp. 893-897, DOI: 10.18668/NG2015.11.12

Article contributed to the Editor 28.08.2015. Approved for publication 15.10.2015. 
The article is the result of research conducted in connection with a project: Development of optimum concepts for unconventional deposits management, considering environmental and social aspects, co-funded by the National Centre for Research and Development as part of the programme BLUE GAS - POLISH SHALE GAS. Contract No. BG1/ResDev/13.

\section{Literature}

[1] Ciechanowska M., Matyasik I., Such P., Kasza P., Lubas J.: Uwarunkowania rozwoju wydobycia gazu z polskich formacji lupkowych. Nafta-Gaz 2013, no. 1, pp. 7-17.

[2] Energy Information Administration: Technically Recoverable Shale Oil and Shale Gas Resources: An Assessment of 137 Shale Formations in 41 Countries Outside the United States. U.S. Department of Energy 2013; http://www.eia.gov/analysis/studies/worldshalegas/archive/2013/pdf/fullreport_2013. pdf (access on: 13.10.2015).

[3] Lubas J., Warnecki M., Szuflita S.: Types of reservoir fluids in the Polish Lower Paleozoic shale formations. Nafta-Gaz 2015, no. 8, pp. 539-548.

[4] Okreslenie skladu wlasciwosci fazowych oraz parametrow PVT plynu zlozowego na poszczegolnych polach eksploatacyjnych w ramach projektu: "Opracowanie optymalnych koncepcji zagospodarowania zloz niekonwencjonalnych z uwzglednieniem aspektow srodowiskowych". Praca Instytutu Nafty i Gazu - PIB, praca w toku, Projekt Blue Gas - Polski Gaz Łupkowy.
[5] Patterson R.: Will the Bakken Red Queen Outrun the Growth in Water Cut? Energy Information Administration, USA 2015; http://peakoilbarrel.com/will-bakken-red-queen-outrun-growthwater-cut/ (access on: 13.10.2015).

[6] Pedersen K. S., Christensen P. L.: Phase behavior of Petroleum Reservoir Fluids. Taylor \& Francis Group 2007, pp. 7-9.

[7] Shale Gas Information Platform: Podstawowe informacje o gazie lupkowym. http://www.shale-gas-information-platform. org/pl/areas/polnisch-basics-of-shale-gas.html (access on: 13.10.2015)

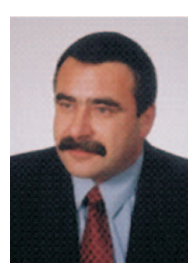

Dr. Andrzej JANOCHA PhD.

Assistant Professor

Department of Exploitation Technology for Reservoir Fluids

Oil and Gas Institute - National Research Institute

ul. Lubicz 25 A, 31-503 Kraków

E-mail: andrzej.janocha@inig.pl

\section{OFFER}

\section{DEPARTMENT OF RESERVOIR FLUID PRODUCTION TECHNOLOGY}

Scope of activity:

- optimisation of production processes and oil and gas processing;

- bioremediation of soils, drilling and production waste contaminated with petroleum substances;

- recultivation of areas contaminated with petroleum substances;

- developmnent of waste and reservoir water treatment technologies for the removal of petroleum contaminations;

- study and selection of paraffin-hydrate inhibitors and de-emulgators used in hydrocarbon reservoir production processes;

- monitoring of alternation in composition of sulphur compounds in underground gas stores, development of activities preventing hydrogen sulphide formation in reservoirs:

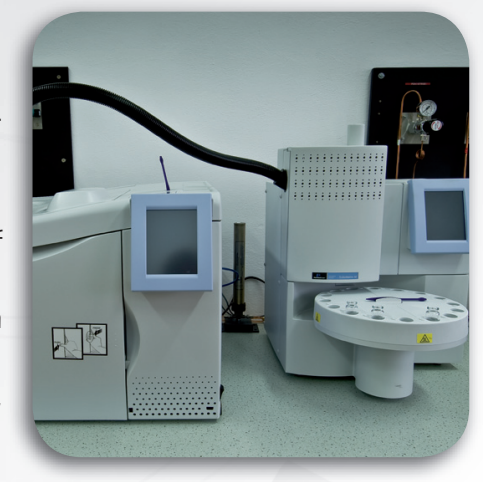

- monitoring of gas quality in industrial grids;

- $\quad$ preparation of catalogue sheets and drawing up of opinions related to safe utilisation of chemicals applied in intensification and production treatment in wellbore conditions;

- analyses of reservoir fluids, soil and wastewater contamination, drilling and production waste. 